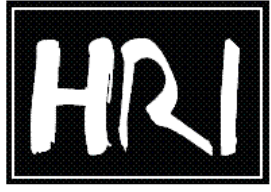

THE HUMAN RIGHTS INSTITUTE

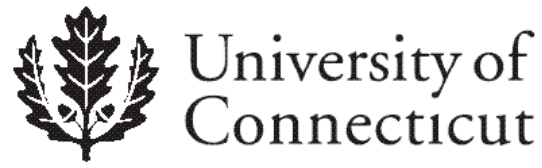

Economic Rights Working Paper Series

\title{
Constitutional Environmental Human Rights: A Descriptive Analysis of 142 National Constitutions
}

Christopher Jeffords

University of Connecticut

Working Paper 16

August 2011

The Human Rights Institute

University of Connecticut

Email: humanrights@uconn.edu

Thom as J. Dodd Research Center

405 Babbidge Road, U-1205

Tel: $860-486-8739$

Storrs, CT, 06269, USA

Fax: 860-486-6332

http:/www.humanrights.uconn.edu/ 
Constitutional Environmental Human Rights: A Descriptive Analysis of 142 National Constitutions

\author{
Christopher Jeffords ${ }^{\dagger}$
}

Suggested running head: Constitutional Environmental Human Rights

Keywords: Constitutions; Environmental Human Rights; Human Right to Water

JEL Classifications: K00, K32, Q50, Q56, Q58

This Version: August 31, 2011

\footnotetext{
${ }^{\dagger}$ Contact: christopher.jeffords@uconn.edu, Department of Agricultural and Resource Economics, University of Connecticut. I thank Amy Jeffords for her love and support, and for helpful editing. I thank Lanse Minkler and Shareen Hertel for helpful comments and suggestions that led to improvements in this paper. I also thank Joshua Berning and participants at the 2011 Economics and Social Rights Group Workshop for thoughtful discussions. I gratefully acknowledge funding support from the Association for Social Economics through the William R. Waters Research Grant. Of course, any errors are my own.
} 


\begin{abstract}
This paper provides a detailed keyword analysis of the 142 out of 198 national constitutions that include at least one reference to the environment as of 2010 . Out of these 142 constitutions, 125 contain provisions that are explicitly related to environmental human rights, and ten include a direct human right to water. Focusing mostly on the language of the provisions and the age of the constitutions (not the age of the provision itself), the analysis provides insight into the extent to which countries are taking environmental human rights seriously. The findings note that constitutions that reference the environment are, on average, generally younger in age than those that do not. This is also the case for developing versus developed countries, and Non-OECD (Organization for Economic Cooperation and Development) versus OECD member countries. Constitutions that have a direct human right to water are, on average, even younger. The paper also develops a simple index of the legal strength of constitutional environmental human rights provisions and offers the data as an alternative, positive (versus subjective) specification to a similar set of data compiled by the Toronto Initiative for Economic and Social Rights (TIESR).
\end{abstract}




\section{Introduction}

Environmental human rights, succinctly defined as entitlements to clean air, water, and soil for present and future generations (Hiskes, 2009), have both conceptual and legal foundations (Sax, 1990). ${ }^{1}$ These rights fit within the basic rights framework outlined by Shue (1996), most notably subsistence rights. Without clean air, water, and soil, humans will be unable to enjoy other rights and life activities (Collins-Chobanian, 2000). Since pollution does not respect geographic and, especially, temporal borders, environmental human rights necessitate a deeper concern for the rights of future generations. Recognizing these unique characteristics of environmental degradation, the first principle of The Stockholm Declaration of 1972 notes the responsibility humans have to protect the environment for both present and future generations. Though its signatories are not legally bound to uphold its principles, much of the language of the declaration forms the basis for modern binding and non-binding instruments and declarations concerning the environment including, but not limited to, The African Charter of Human and People's Rights, the Brundtland Report, and the Ksentini Report (Hiskes, 2010). Given these foundations, environmental human rights impose specific duties and obligations on governments, and have vast implications for government efforts to respect, protect, and fulfill said rights, including the nature of interference and definition of rights violations. ${ }^{2}$

\footnotetext{
${ }^{1}$ For similar definitions see, generally, Sax (1990), Shelton (1991), Weiss (1992), Collins-Chobanian (2000), and Lercher (2007).

${ }^{2}$ Collins-Chobanian (2000) notes that interference with environmental rights can only be for an overriding justification. This includes, for example, adding a harmful chemical to a water supply to eradicate an even more harmful bacteria. It does not include, however, "harms to be imposed in pursuit of goals that do not outweigh the harms (page 146).". Thoroughly defining interference, and a subsequent rights violation, is a practical difficulty. For example, water can be physically limited in supply and has various industrial, agricultural, and recreational uses that complicate government efforts to respect, protect, and fulfill the human right to water.
} 
Governments seem to take these obligations seriously as the world has seen a significant increase in the number of multinational and bilateral treaties and declarations concerned with recognizing a human right to a safe, healthy, or clean environment (Herz, 2000; Hiskes, 2010). This is also true for the human right to water (Scanlon et al., 1999). However the question remains to what extent governments are trying to formalize and institutionalize these rights in national policy and law. Evidence of government effort can be found by looking closely at national constitutions, the topic of this paper.

As of 2010, out of 198 national constitutions of developed and developing countries across every continent, 142 include at least one reference to the environment, in a broad sense. Of these 142, 125 have a specific environmental human rights provision or at least the makings of one, and ten include a direct human right to water. These findings may already surprise many, but to further explore the nature of constitutional environmental human rights this paper employs a keyword analysis to provide deeper insight into each provision and the nature of justiciability. Furthermore, the keyword analysis is used to form a simple positive index of provision strength based on six to seven specific categories of language. The index is offered as an alternative approach to interpreting the language of constitutional environmental human rights provisions as either directive principles or enforceable law (Jung \& Rosevear, 2011).

Minkler (2009) offers an explanation of the differences between directive principles and enforceable law within the context of economic rights. Directive principles are "important goals meant to guide policy action (page 381)." Policymakers that fail to incorporate these goals into actual policy face potential reelection repercussions, at least to the extent that the policymakers' constituency is truly concerned with the underlying claims associated with these directive principles. Including a constitutional provision as enforceable law, on the other hand, creates a legal entitlement that acts to "tie policymakers' hands because it would force them to concoct policies and devote resources for that purpose (page 382)." En- 
forceable law thus provides legal action and penalties for rights violations. Whether or not a constitutional provision is interpreted as a directive principle or enforceable law is important for environmental rights outcomes. The nature of the provision imposes different constraints on government efforts to respect, protect, and fulfill the right, where the constraints are often expressed as duties and obligations. Because the distinction between directive principles and enforceable law is not always clear, empirical analyses linking provisions to rights outcomes are complicated by potential measurement error stemming from subjective interpretation of constitutional language.

Further complicating the nature of justiciability is the presence of negating statements or provisions before or after an existing constitutional environmental human rights provision. These statements, which either directly negate the scale and scope of the environmental rights provisions, or refer the responsibility of the environment to the domain of law, are important caveats to government duties and obligations. As of 2010, these occurred in 19 constitutions thereby relinquishing some degree of government responsibility for environmental human rights violations.

Interpreting the justiciability of a constitutional environmental human rights provision based solely on keywords and phrases is clearly a cumbersome task, but this burden is also faced by all constitutional human rights. Furthermore, government efforts to respect, protect, and fulfill economic and social rights are hampered by resource constraints, as evidenced in the language of Article Two of the International Covenant on Economic, Social, and Cultural Rights (ICESCR). For environmental human rights, however, these resource constraints arguably include the physical parameters of the world, in addition to the economic, political, and financial ones. Such physical constraints make environmental human rights fundamentally different from other human rights. ${ }^{3}$ Take, for example, the human

\footnotetext{
${ }^{3}$ I recognize that the increased costs associated with procuring scarce natural resources could be capitalized into a country's financial and economic constraints, however by separately breaking them out, the vagueness of the language of the ICESCR is further exposed.
} 
right to water. Gleick (1998) notes that the human right to water entails access to a basic minimum consumption requirement of roughly 13 gallons per person per day. This includes drinking water (10\%), sanitation services (40\%), bathing (30\%), and food preparation (10\%), but excludes the amount of water required to grow the daily food needs of an individual, which is an additional 713 gallons. For an enforceable human right to water, is the minimum requirement 13 or 726 gallons? The difference between the two is clearly nontrivial from a pure quantity perspective, to say nothing of quality differences. But a minimum requirement is only part of the story. Recognizing a human right to water presents interesting legal questions for the current water consumption habits of households with pets, pools, jacuzzis, lawns and gardens, bird baths, water pistols, and so on. Would these households be grandfathered into a new legal structure or be forced to pay, financially and/or legally, for their possible overconsumption? In this sense, the problem becomes strikingly similar to the tragedy of the commons, where the unregulated use of water could ultimately lead to resource exhaustion, and regressively affect poorer households unable to afford more expensive stocks of water. ${ }^{4}$

Despite these practical difficulties, since the middle of the 20th century the human right to water has gained significant traction in many international, national, and regional legally binding and non-legally binding instruments (Scanlon, Cassar, \& Nemes, 1999). This has happened directly in that the right is explicitly delineated and recognized separately from

${ }^{4}$ See Hardin (1968) and Ostrom (1990) for a discussion of the tragedy of the commons. In a theoretical model of the human right to water embedded in a standard nonrenewable resources framework with a backstop technology, Jeffords and Shah (2011) find that fulfilling the human right to water through government fiscal policy (i.e., tax and subsidy policy) is a difficult task, often requiring a certain degree of income inequality among poor and rich households. They also find that policies aimed at reducing the price of the backstop, increasing water conservation efforts, spurring income growth, including firm tax proceeds, or extraterritorial assistance can mitigate the need for such income inequality, but more importantly, for the government to enact its human rights fiscal policy. 
broader environmental human rights, and indirectly, or implicitly, through some broader concern such as the right to an adequate amount of food or standard of living. ${ }^{5}$ This is also the case within national constitutions. In fact, as of 2010, only ten explicitly recognize the human right to water in a separate provision or as a section of an overall environmental human rights provision. If, however, environmental human rights imply the human right to water, then ten might be an underestimate of the true number of countries that have recognized this right, albeit indirectly and to varying degrees of justiciability. ${ }^{6}$

As populations grow and countries transition from developing to developed, the role of constitutional environmental human rights in potentially driving positive environmental outcomes will become increasingly important. Therefore this paper not only looks at whether or not a country has constitutionalized environmental human rights, but also how these provisions can be characterized by strength, number, and age. This analysis is important because researchers need to know how constitutional provisions differ before they can assess

\footnotetext{
${ }^{5}$ From 1945 through 1989, nine legally binding international instruments were developed, starting with the United Nations Charter and ending with The Convention on the Rights of the Child (Scanlon et al., 1999, pp. 35-37). From 1948 through 2002, 21 non-legally binding international instruments were created beginning with The Universal Declaration of Human Rights through the World Summit on Sustainable Development - 71\% of these instruments were formed over 1990-2002 (Scanlon et al., 1999, pp. 37-41). With varying dates, 49 national instruments (i.e., constitutions) include environmental human rights language as of the date of publication of their article. In addition, eight state constitutions in the United States recognize the right to a healthy environment. Lastly, from 1981-2002, eight regional instruments were formed starting with the African Charter on Human and People's Rights (Scanlon et al., 1999, pp. 41-42).
}

${ }^{6}$ Perhaps the biggest step toward recognizing a human right to water occurred in 2010. Following the framework of General Comment 15 (The Right to Water), the United Nations General Assembly declared "the right to safe and clean drinking water and sanitation as a human right that is essential for the full enjoyment of life and all human rights." For more on this, see the General Assembly document: A/64L.63/Rev.1. 
whether or not they matter in affecting environmental human rights outcomes. The method I offer here has the attractive feature that it counts fundamental keywords in constitutions which thereby avoids the potential measurement error of interpreting the meaning of specific language found in alternative approaches, such as Jung and Rosevear (2011).

To characterize the nature of constitutional environmental human rights provisions and to develop the index of provision strength, the descriptive analysis proceeds in the following way. First, the main data generating process is described including a summary of the findings and a note on the 17 countries that are ultimately excluded from the set of 142 . This is followed by a broad summary of the 125 constitutional environmental human rights provisions and a brief description of the secondary data generating process. The categories of language used in the secondary analysis are then outlined inclusive of the descriptive findings. Using the keyword categories, the index of provision strength is developed and discussed in detail. The data, including the strength index, are then briefly compared to a subset of data from the Toronto Initiative for Social and Economic Rights (TIESR). Interpreting the language of constitutional provisions for a broad class of human rights, the TIESR data include the right to a safe or healthy environment (HENV), duty of the state to protect the environment (ENVP), and the right to access to food and/or water (FOWA). ${ }^{7}$ The final section concludes and provides recommendations for future research.

\footnotetext{
${ }^{7}$ The entire TIESR dataset covers 136 developing countries in every continent but Australia. Each right in the data is coded as absent, an aspirational directive principle, or enforceable law. Of these 136, there are 95 countries that can be directly compared to the data described in this paper.
} 


\section{Main Data Generating Process}

The data are derived primarily from Constitution Finder, a website run by The T.C. Williams School of Law at the University of Richmond. ${ }^{8}$ The site provides direct links to the constitutions of most countries, including the year of the constitution and notes about the most recent set of included amendments. For constitutions that were in English, the primary task was to determine if there was a provision referencing the environment. To do so, a keyword search was conducted for the following words, including relevant variations and combinations: environment, natur (to capture nature and natural), physical, resource, and water. If the word was found, the entire provision was extracted and placed in a separate document, no matter the context in which the word was placed. For the 23 constitutions that were not posted in English, the task of extracting keywords was slightly more difficult. In some cases, the full constitution was translated from the native language to English and the procedure outlined above was followed. For other cases, the main keywords were converted to the native language and the search proceeded in the native language. When a keyword was found, the entire article was extracted, translated to English, and placed in a separate document. ${ }^{9}$ Once all of the data was in English and in a single document, irrelevant articles that referenced some other non-physical environment were noted and discarded.

\footnotetext{
${ }^{8}$ Additional data, when unavailable via Constitution Finder, was gathered from the International Constitutional Law Project at: http://www.servat.unibe.ch/icl/info.html.

${ }^{9}$ This was a tedious process as there tended to be more than one translation for the main keywords into the native languages. For example, the word environment in English has five French translations (at least according to Google Translate).
} 


\subsection{At Least One Reference to the Environment}

Tables 1 and 2 display the number of national constitutions, by level of development and continent, that include at least one reference to the environment based on the keywords discussed above. In total, out of the 198 constitutions, 142 include a single reference to the environment and 56 do not. For example, Article 50 of Ukraine's Constitution (1996) states, "everyone has the right to an environment that is safe for life and health,...," while Article 145 of Honduras' Constitution (1982) states, "[...] the State shall retain the right environment to protect the health of people."

On average, the constitutions that mention the environment tend to be considerably younger than those that do not, as noted in Table 1. Furthermore, the constitutions of developing and Non-OECD (Organization for Economic Co-operation and Development) countries that mention the environment are relatively younger compared to their developed and OECD-member counterparts. ${ }^{10}$ The average age of constitutions that reference the environment from developing countries is 21.38 years compared to 48.09 years for developed countries. For developing countries, the average age of constitutions that do not reference the environment is 36.73 years compared to 92 for developed countries. Table 1 also illustrates that anywhere between $65-75 \%$ of countries reference the environment in the constitution depending on development/membership status.

Table 2 shows that within continents, constitutions with at least one reference to the environment are also younger compared to those without a reference. On average, the youngest constitutions that reference the environment are from Africa and the oldest, Australia. The percentage of constitutions that reference the environment is lowest in Australia (44\%) and highest in South America (100\%).

\footnotetext{
${ }^{10}$ The classification of countries as developed or developing is from the Central Intelligence Agency (CIA) World Factbook.
} 
While interesting, simply mentioning the environment does not necessarily indicate the presence of an environmental human right. In order to determine the strength of each provision, as well as the nature of the language, an extended keyword analysis was conducted, the results of which follow below. But first, a note on the countries that are excluded from the secondary analysis.

\section{$2.2 \quad$ Excluded Countries}

Owing to the way in which the environment was referenced, 17 countries are excluded from the analysis. ${ }^{11}$ The five examples provided below illustrate the reason for these countries being included in the original set of 142 as well as for being currently excluded:

- Equatorial Guinea (1991), Sections 28a and 28b: The resources and services reserved to the public sector shall be: mines and hydrocarbons; and services in charge of distributing water and electricity.

- Fiji (1997), Article 186, Section 4c: A law fixing amounts under subsection (3) must require that account be taken of: the risk of environmental damage.

- France (1958), Article 70: The Economic, Social and Environmental Council may also be consulted by the Government or Parliament on any economic, social or environmental issue. The Government may also consult it on Programming Bills setting down the multi-annual guidelines for public finances. Any plan or Programming Bill of an economic, social or environmental nature shall be submitted to it for its opinion.

- Honduras (1982), Article 145: The State shall retain the right environment to protect the health of people.

\footnotetext{
${ }^{11}$ These 17 countries are: Australia, Austria, Cyprus, Equatorial Guinea, Fiji, France, Gabon, Honduras, Ireland, Jamaica, Mauritania, Philippines, Puerto Rico, Saint Lucia, Tanzania, Thailand, and Tuvalu.
} 
- Mauritania (1991), Article 57: The following are the domain of the law: general regulation of water, mines, and hydro-carbons, fishing and the merchant marine, fauna, flora, and the environment.

These 5 articles, and the remaining 12, mention the environment or natural resources in some way, but it is not clear if they form any kind of meaningful basis for environmental human rights. As noted above, an environmental human right is an entitlement to some clean natural resource for present and future generations. None of these articles seem to impose duties or obligations, whether interpreted as enforceable law or directive principles, on the State. Rather, each provision seems to simply note that the government is in charge of the environment, in a very broad sense, and that any action which affects the environment must be accompanied by some sort of governmental oversight. Perhaps these are relevant from a pure policy perspective, outside of the scope of a directive principle, but the focus of this paper is to examine the nature of constitutional environmental human rights.

\section{$2.3 \quad$ Negating Statements}

Before examining constitutional environmental human rights proper, it is necessary to quickly discuss the presence of negating statements. Occurring in 19 constitutions, these statements mitigate the legal strength of constitutional environmental human rights and leave citizens with little recourse to address rights violations. ${ }^{12}$ As an example, consider the following excerpt taken from Article 59.1.e of Albania's Constitution (1998), which is part of a broader social objectives chapter:

The state, within its constitutional powers and the means at its disposal, aims to

\footnotetext{
${ }^{12}$ The 19 countries are: Albania, Burkina Faso, Central African Republic, Chad, Chile, Comoros, Congo (Brazzaville), Cook Islands, Costa Rica, Estonia, Italy, Madagascar, Niger, Paraguay, Sierra Leone, South Korea, Sri Lanka, Togo, and Vanuatu.
} 
supplement private initiative and responsibility with a healthy and ecologically adequate environment for the present and future generations.

Which is immediately followed by:

Fulfillment of social objectives may not be claimed directly in court. The law defines the conditions and extent to which the realization of these objectives can be claimed.

Failing to account for statements like these could positively bias the estimate of constitutional environmental human rights provisions on rights outcomes. This sort of equivocating discounts government efforts to respect, protect, and fulfill environmental human rights.

\subsection{Constitutional Environmental Human Rights Provisions}

Tables 3 and 4 display the number of national constitutions, by level of development and continent, that include an environmental human right directly, regardless of degree of justiciability. After dropping the 17 countries noted above, 125 countries remain. In other words, $63 \%$ of national constitutions as of 2010 include some form of an environmental human right of a varying degree of justiciability.

Out of 164 developing countries, 107 include an environmental human right compared to 18 out of 34 developed countries. Perhaps not surprisingly, the constitutions that include a right are also younger than those that do not include (i.e., exclude) a right. Furthermore, comparing the included group of Tables 3 and 4 to the mention group of Tables 1 and 2 , the average age of the constitutions that include a right has fallen across each growth classification, as well as by continent. ${ }^{13}$ This is also true for the excluded group compared to the no mention group, with the exception of Asia and Australia.

\footnotetext{
${ }^{13}$ It is possible that constitutions with environmental human rights provisions tend to be younger within developing and Non-OECD countries could simply a definitional artifact or an issue of selection.
} 
This analysis so far does not take into consideration the strength of each provision, which is perhaps the most important aspect for driving rights outcomes. To do so, a secondary keyword analysis was performed on each provision, the explanation and results of which follow below.

\section{Secondary Data Generating Process}

Once each constitutional environmental human right was sorted out, an extended keyword analysis was conducted to further examine the strength of each provision. The presence of a single word from a group of seven categories of language was coded as one and zero otherwise. That is, if a single word occurred more than once within a provision, all that was coded was the presence or absence, not the total count. The seven language categories are described below.

\subsection{Category Descriptions and Justifications}

Category One (1) includes keywords and phrases associated with State duties, obligations, protections, and so on. The language of Category Two (2) is generally weaker but is also associated with the State. It includes such language as "shall ensure," "take measures," "must see to," and "fundamental objective." Thus, the major difference between these two categories is the strength of the language. ${ }^{14}$

Category Three (3) includes language regarding a citizen's right to be informed about the status of the environment and provides citizens with an avenue to seek information. The right to information is noted in Section 12.c.iv of General Comment 15, though with respect

\footnotetext{
${ }^{14}$ Citing Sunstein (2004), who argues for constitutionalizing certain economic rights, Minkler (2009) notes a similar distinction with respect to economic rights provisions. Category One, independently, could be considered the language of enforceable law, while the language of Category Two is similar to directive principles.
} 
to the human right to water. Extending this right to environmental human rights in general necessitates information about (at least) air, water and soil, that should be readily and freely available and accessible to all. This is not necessarily a environmental human right proper as the environment could be pristine or irreparably polluted, so long as citizens can freely access this information, a right has not been violated. Nonetheless, its relevance as a singular provision or for adding potential legal strength to an existing constitutional environmental human right cannot be ignored.

Category Four (4) refers directly to a citizen's right to a clean or healthy environment, separate from the duties and obligations of the State to provide a clean or healthy environment as outlined in Categories One and Two. This distinction is also noted by Jung and Rosevear (2011) in HENV and ENVP respectively. However, it is not clear that the two are independent provisions rather than jointly forming the basis of an environmental human right. Explicitly including both types of language likely acts to form a stronger (in a legal sense), more explicit environmental human right. Otherwise, this type of double-counting begs the question of why other economic and social rights are not also delineated in this way in the TIESR data (and within national constitutions) - the right to social security and duty of the state to protect social security; the right to rest or leisure and duty of the state to protect rest or leisure; and so on.

Category Five (5) denotes the explicit concern for future generations as written into the environmental human rights provision. Hiskes' (2009) definition of human rights is carefully derived to include a concern for future generations. Channeling Rawls (1999), Hiskes (2010) further outlines environmental human rights as not only expanding geographical borders, but also temporal boundaries in an intergenerational justice sense. Within the context of sustainability, Weiss (1992) argues that each generation holds the planet in trust for other generations, placing obligations on current generations to protect and preserve the environment for future generations. Economists have also tackled the notion of sustainability from an intergenerational perspective. Citing Howarth (1997) and Barrett (1996), Padilla (2002) 
argues that present generations have the ability to augment the conditions of nature that the future will inherit and, because of this, present generations have a direct responsibility to the future. ${ }^{15}$ Whether the concern is for some future, unborn generation, or for the myriad living generations of humans that vary in degree of autonomous decision-making capacity (i.e., children), individuals know their own preferences best and can only guess at the preferences of others. In other words, it is not clear if future generations will have the same preferences for environmental human rights as the current generations do. Governments can only guess these preferences, thus further complicating national instantiation of constitutional environmental human rights.

Category Six (6) includes language about duties and obligations as applying to citizens and (the royal) everyone. ${ }^{16}$ A noted conceptual problem with such language is that by making everyone responsible, that is, a duty bearing addressee of environmental human rights, no one may feel the burden of any responsibility. ${ }^{17}$ Nevertheless, even if there are practical difficulties in legally enforcing such a provision (at least the duties of protect and fulfill), its real power may come from its persuasiveness as a directive principle.

\footnotetext{
${ }^{15}$ Based on a contractarian premise, Howarth (1997) argues for sustainability, or sustainable development, through property rights whereby the present endows the future with a "structured bequest package" that provides at least undiminished stocks of natural resources and environmental quality. See Beckerman (1997) for a critique of the link between intergenerational equity or justice and sustainability.

${ }^{16}$ Shrader-Frechette (2007) offers a discussion about a citizens' ethical responsibility to stop environmental injustice, broadly defined as the disproportionate burden of environmental harm regressively affecting children, poor people, minorities, or other subgroups. Based on the benefits that some citizens may have received or currently receive from environmental injustice, these citizens therefore have a duty to stop doing so. Secondly, citizens have a democratic responsibility to stop environmental injustice.
}

\footnotetext{
${ }^{17}$ See Hiskes (2010) for a discussion of the addressee within the context of environmental human rights.
} 
Category Seven (7) denotes the constitutions that explicitly include a human right to water. As noted above, the human right to access to clean water (and sanitation) has received increasing national and international attention over the last 60 plus years, most notably in 2010 .

With the seven categories explicitly defined, the next section discusses the results of the secondary keyword analysis.

\section{Keyword Summary and Category Analysis}

Figure 1 shows the frequency of reference to the seven categories of language discussed above. Tables 5, 6, and 7 display, for each country with an environmental human rights provision $(\mathrm{n}=125)$, the instance of a specific word or phrase from each category. A one indicates the presence of the word(s) and/or phrase(s), and zero indicates otherwise. Examples of the language of each of the seven categories included in Figure 1, and Tables 5, 6, and 7, are discussed below.

\subsection{Category One (1) - State Duties}

Category One is comprised of keywords and phrases associated with the State. The language is generally strong and, independently, might be interpreted as enforceable law. The keywords include, but are not limited to, the following: duty, will protect, obliged, and incumbent upon. These keywords and phrases occurred in 27 constitutions and five examples are provided below: ${ }^{18}$

- Afghanistan (2004), Article 15: The state is obliged to adopt necessary measures for

\footnotetext{
${ }^{18}$ The 27 countries are: Afghanistan, Azerbaijan, Brazil, Central African Republic, Chile, Columbia, Congo (Kinshasa), Costa Rica, El Salvador, Greece, Guyana, Iran, Latvia, Maldives, Mali, Mozambique, Nicaragua, Niger, Panama, Peru, Portugal, Senegal, Seychelles, South Africa, Sudan, Turkey, and Vietnam.
} 
safeguarding forests and the environment.

- Chile (1980), Article 8: The right to live in an environment free from contamination. It is the duty of the State to watch over the protection of this right and the preservation of nature.

- El Salvador (1983), Article 117: It is the duty of the State to protect natural resources and the diversity and integrity of the environment, to ensure sustainable development.

- Mali (1992), Article 15: Every person has a right to a healthy environment. The protection and defense of the environment and the promotion of the quality of life is a duty of everyone and of the State.

- Turkey (1982), Article 56: It is the duty of the state and citizens to improve the natural environment, and to prevent environmental pollution.

\subsection{Category Two (2) - State Objectives}

Category Two is comprised of keywords and phrases also associated with the State but with weaker language compared to Category One, and could independently be viewed as directive principles. These include, but are not limited to, the following: fundamental objective, must see to, manage, shall ensure, and take measures. These keywords and phrases occurred in 82 constitutions and five examples are provided below: ${ }^{19}$

\footnotetext{
${ }^{19}$ The 82 countries are: Andorra, Angola, Argentina, Armenia, Bahrain, Benin, Bolivia, Bulgaria, Cambodia, Cameroon, Cape Verde, Cayman Islands, Chad, China, Congo (Brazzaville), Congo (Kinshasa), Cook Islands, Costa Rica, Croatia, Cuba, Czech Republic, East Timor (Timor-Leste), Ecuador, Eritrea, Ethiopia, Finland, Gambia, Georgia, Germany, Ghana, Guatemala, Haiti, Hungary, India, Iraq, Italy, Kazakhstan, Kuwait, Kyrgyzstan, Lesotho, Lithuania, Macedonia, Madagascar, Malawi, Malta, Mongolia, Montenegro, Mozambique, Nepal, Netherlands, Niger, Nigeria, North Korea, Oman, Palau, Peru, Poland, Qatar, Romania, San Marino, Sao Tome and Principe, Saudi Arabia, Serbia, Sierra Leone, Slovakia, Slovenia, South Korea, Spain, Sri Lanka, Suriname, Swaziland, Sweden, Switzerland, Taiwan, Tajikistan, Togo, Turkmenistan,
} 
- Angola (1992), Article 12, Section 2: The State shall promote the protection and conservation of natural resources guiding the exploitation and use thereof for the benefit of the community as a whole.

- Bulgaria (1991), Article 15: The Republic of Bulgaria shall ensure the protection and reproduction of the environment, the conservation of living Nature in all its variety, and the sensible utilization of the country's natural and other resources.

- Ghana (1992), Article 36, Section 9: The State shall take appropriate measures needed to protect and safeguard the national environment for posterity; and shall seek cooperation with other states and bodies for purposes of protecting the wider international environment for mankind.

- Kazakhstan (1995), Article 31, Section 1: The state shall set an objective to protect the environment favorable for the life and health of the person.

- Poland (1997), Article 5: The Republic of Poland shall safeguard the independence and integrity of its territory and ensure the freedoms and rights of persons and citizens, the security of the citizens, safeguard the national heritage and shall ensure the protection of the natural environment pursuant to the principles of sustainable development.

\subsection{Category Three (3) - Right to Information}

Category Three refers to a citizens' right to be informed about the status of the environment. The main keyword was information, or some variation of it. The keywords or phrases occurred in 16 constitutions and five examples are provided below: ${ }^{20}$

Uruguay, Uzbekistan, and Venezuela.

\footnotetext{
${ }^{20}$ The 16 countries are: Albania, Argentina, Azerbaijan, Belarus, Cape Verde, Cook Islands, Georgia, Latvia, Moldova, Montenegro, Norway, Poland, Russia, Serbia, Slovakia, and Ukraine.
} 
- Azerbaijan (1978), Article 39, Section 2: Everyone has the right to obtain information about the real condition of the environment and to receive compensation for the health or property damage caused by the violation of ecological law.

- Belarus (1994), Article 34: Citizens of the Republic of Belarus shall be guaranteed the right to receive, store, and disseminate complete, reliable, and timely information on the activities of state bodies and public associations, on political, economic, and international life, and on the state of the environment.

- Georgia (1995), Article 37, Section 5: A person shall have the right to receive complete, objective and timely information as to a state of his/her working and living environment.

- Moldova (1994), Article 37, Section 2: The State guarantees every citizen the right of free access to truthful information regarding the state of the natural environment, the living and working conditions, and the quality of food products and household appliances.

- Poland (1997), Article 74, Section 3: Everyone shall have the right to be informed of the quality of the environment and its protection.

\subsection{Category Four (4) - Right to a Healthy Environment}

Category Four refers explicitly to a citizen's right to a healthy or clean environment. The language is generally strong and includes, but is not limited to, the following: right to a healthy environment, right to a clean environment, safe, healthy, and favorable (all within the context of the natural environment). These keywords and phrases occurred in 60 constitutions and five examples are provided below: ${ }^{21}$

\footnotetext{
${ }^{21}$ The 60 countries are: Angola, Argentina, Azerbaijan, Belarus, Belgium, Benin, Bolivia, British Virgin Islands, Bulgaria, Burkina Faso, Cameroon, Cape Verde, Chad, Central African Republic, Chile, Colombia,
} 
- Benin (1990), Article 27: Every person has the right to a healthy, satisfying and lasting environment and has the duty to defend it. The state shall watch over the protection of the environment.

- Chad (1996), Article 47: Every person has the right to a healthy environment.

- Macedonia (1991), Article 43, Section 1: Everyone has the right to a healthy environment to live in.

- Russia (1993), Article 42: Everyone shall have the right to a favorable environment, reliable information about its condition and to compensation for the damage caused to his or her health or property by ecological violations.

- Ukraine (1996), Article 50, Section 3: Everyone has the right to an environment that is safe for life and health, and to compensation for damages inflicted through the violation of this right. Everyone is guaranteed the right of free access to information about the environmental situation, the quality of food and consumer goods, and also the right to disseminate such information. No one shall make such information secret.

\subsection{Category Five (5) - Future Generations}

Category Five refers to the concern for future generations as explicitly written into some constitutional environmental human rights provision. The main keywords were future, generation, and sustainable development. These occurred in 35 constitutions and five examples Comoros, Congo (Brazzaville), Congo (Kinshasa), Cook Islands, Costa Rica, Côte d'Ivoire, Croatia, East Timor (Timor-Leste), Ecuador, El Salvador, Georgia, Hungary, Indonesia, Italy, Kyrgyzstan, Latvia, Macedonia, Maldives, Mali, Moldova, Mongolia, Montenegro, Mozambique, Nepal, Nicaragua, Niger, Norway, Paraguay, Peru, Portugal, Russia, Sao Tome and Principe, Senegal, Serbia, Seychelles, Slovakia, Slovenia, South Africa, South Korea, Spain, Sudan, Togo, Turkey, and Ukraine. 
are provided below: ${ }^{22}$

- Albania (1998), Article 59, Section 1, Subsection E: The state, within its constitutional powers and the means at its disposal, aims to supplement private initiative and responsibility with: a healthy and ecologically adequate environment for the present and future generations.

- Eritrea (1996), Article 10, Section 3: The State shall have the responsibility to regulate all land, water and natural resources and to ensure their management in a balanced and sustainable manner and in the interest of the present and future generations; and to create the right conditions for securing the participation of the people to safeguard the environment.

- Lesotho (1993), Article 36: Lesotho shall adopt policies designed to protect and enhance the natural and cultural environment of Lesotho for the benefit of both present and future generations and shall endeavor to assure to all citizens a sound and safe environment adequate for their health and well-being.

- Qatar (1993), Article 33: The State shall preserve the environment and its natural balance in order to achieve comprehensive and sustainable development for all generations.

- Uganda (1995), Article 27: This is to promote development and awareness for proper management of land, air and water resources for the present and future generations.

\footnotetext{
${ }^{22}$ The 35 countries are: Albania, Andorra, Argentina, Armenia, Bolivia, Brazil, British Virgin Islands, Cayman Islands, Columbia, Cuba, East Timor (Timor-Leste), Ecuador, El Salvador, Eritrea, Ethiopia, Georgia, Germany, Guyana, Iran, Lesotho, Malawi, Maldives, Mozambique, Norway, Papua New Guinea, Peru, Poland, Qatar, Switzerland, Uganda, Uruguay, Vanuatu, and Venezuela.
} 


\subsection{Category Six (6) - A General Duty to Respect}

Category Six refers to duty, in a general sense. This includes the duty of citizens and a catch-all category, everyone, to respect, defend, conserve, etc. the environment or nature. These keywords and phrases occurred in 59 constitutions and five examples are provided below: ${ }^{23}$

- Cape Verde (1992), Article 7, Section 1, Subsection E: Everyone shall have the right to a healthy life and ecologically balanced environment and the duty to defend and conserve it.

- Estonia (1992), Article 53: Everyone has a duty to preserve the human and natural environment and to compensate for damage caused to the environment by him or her. The procedure for compensation shall be provided by law.

- Kyrgyzstan (2007), Article 48, Section 3: Everyone must take care of the environment, flora, and fauna.

- Mongolia (1992), Article 17, Section 2: It is a sacred duty for every citizen to work, protect his or her health, bring up and educate his or her children and to protect nature and the environment.

- Seychelles (1993), Article 40, Section E: It shall be the duty of every citizen of Seychelles to protect, preserve, and improve the environment.

${ }^{23}$ The 59 countries are: Azerbaijan, Belarus, Benin, Brazil, Bulgaria, Burkina Faso, Cameroon, Cape Verde, Chad, Colombia, Comoros, Congo (Brazzaville), Congo (Kinshasa), Côte d'Ivoire, East Timor (Timor-Leste), Ecuador, Estonia, Finland, Gambia, Georgia, Ghana, Guyana, Haiti, India, Iraq, Kazakhstan, Kosovo, Kyrgyzstan, Laos, Lithuania, Macedonia, Madagascar, Maldives, Mali, Moldova, Mongolia, Montenegro, Mozambique, Myanmar, Niger, North Korea, Panama, Papua New Guinea, Poland, Portugal, Russia, Serbia, Seychelles, Slovakia, South Korea, Spain, Sudan, Swaziland, Tajikistan, Turkey, Uganda, Uzbekistan, Vanuatu, and Venezuela. 


\subsection{Category Seven (7) - Right to Water}

There are 10 constitutions containing a specific human right to water: Ecuador, Ethiopia, Gambia, Kenya, Maldives, Panama, South Africa, Uganda, Uruguay, and Zambia. The specific articles are listed below:

- Ecuador (2008), Section 2.15: Energy sovereignty will not be achieved at the expense of food sovereignty, nor affect the right to water. Article 67, Section 2: The right to a dignified life, to ensure the health, food and nutrition, drinking water, housing, sanitation, education, labor, employment, and leisure.

- Ethiopia (1998), Article 90: Every Ethiopian is entitled, within the limits of the country's resources to, ... clean water.

- Gambia (1997), Social Objectives 216, Section 4: The State shall endeavor to facilitate equal access to clean and safe water, adequate health and medical services, habitable shelter, sufficient food and security to all persons.

- Kenya (2010), Article 43: Every person has the right - to clean and safe water in adequate quantities.

- Maldives (2008), Section 23a: Every citizen has the following rights pursuant to this Constitution, and the State undertakes to achieve the progressive realization of these rights by reasonable measures within its ability and resources: adequate and nutritious food and clean water.

- Panama (1994), Chapter 7, Article 118: Is the fundamental duty of the State to ensure that people living in a healthy environment free of pollution, where air, water and food meet requirements of the proper development of human life.

- South Africa (1996), Article 14: Everyone has the right to have access to sufficient food and water. 
- Uganda (1995), Article 27b: The State shall endeavor to fulfill the fundamental rights of all Ugandans to social justice and economic development and shall, in particular, ensure that ... all Ugandans enjoy rights and opportunities and access to education, health services, clean and safe water, decent shelter, adequate clothing, food, security and pension and retirements benefits.

- Uruguay (1967), Article 47: The protection of the environment is of general interest. People should refrain from any act causing depredation, destruction or serious environmental pollution. Law shall regulate this provision and may provide penalties for violators. Water is a natural resource essential to life. Access to safe water and access to sanitation are basic human rights.

- Zambia (1998), Article 112: The state shall endeavor to provide clean and safe water.

\section{A Simple Index of Provision Strength}

Summing across each of the categories can provide an indication of the legal strength of a constitutional environmental human rights provision. Treating the entire set of language surrounding the natural environment as forming the basis of an environmental human right is fundamentally different from defining the nature of the provision as a directive principle or enforceable law. However, it is unclear if this sum should be across Categories 1-6 or 1-7. The human right to water is arguably legally nested within constitutional environmental human rights in general, but the converse is not necessarily true. Having an explicit human right to water says nothing of air and soil, while a general environmental human right, based on the definition provided in the introduction, covers air, soil, and water. Further research should consider this distinction, both empirically and theoretically. Empirically, the two are highly correlated, thus for the sake of inference might serve the same purpose. Theoretically or conceptually, however, the distinction is important because the legal duties and obligations imposed on the government could be drastically different if the constitution includes solely 
an environmental human right versus a direct human right to water. For the latter case, the government might never be held responsible for polluted air and soil. Without taking a stand on which summation is empirically and theoretically more robust, the following analysis considers both.

Table 8 and Figures 2 and 3 illustrate the distribution of countries across the category summations by average age and development status. For Categories 1-6, the majority of countries have a score of two and the average score (not included in the table) is 2.232. Only one country has a score of zero (Kenya) and two have a score of five (Georgia and Mozambique); none score the maximum of six. There seems to be no discernable pattern between the category summation and the average age of constitutions, although those countries with a score of four or five are both under the aggregate average age of the 125 constitutions (23.51). The majority of developing countries have a score of two while developed countries are almost evenly spread across scores one, two, and three, with a majority having only one.

For Categories 1-7, the majority of countries also have a score of two and the average score is slightly higher at 2.312. Based on this summation, no countries have a score of zero, six, or seven. The average age of the countries with a score of five has dropped considerably to 10.25. In fact, across all scores with the exception of four, the average age of constitutions has fallen. The distribution of developed countries has changed slightly, with one country moving from a score of two to three (South Africa). Comparing Figures 2 and 3, the summation across Categories 1-7 yields a distribution that is slightly more right or positively skewed (i.e., the right tail of the distribution is longer than the left tail).

Table 9 illustrates the correlation matrix for the seven keyword categories and a total across the first six and all seven. The correlation coefficients between the totals and Category 1 are positive at 0.302 and 0.308 respectively, and significant at the $1 \%$ level. These correlations are much weaker with respect to Category 2 and not statistically significant. In other words, while positively related to both the strong and weak language of Categories One and Two respectively, having a larger total count across the keywords is more strongly 
(and positively) associated with the language of Category One. Perhaps this lends credence to coding these specific provisions as enforceable law. However, for the variety of language within each constitutional environmental human rights provision, subjectively coding the provision may not be as robust of an explanatory variable in an empirical analysis as the finer keyword approach offered in this paper. Only validity tests in further research will tell. While both coding schemes are prone to measurement error, a subjective interpretation is likely more so because of the potential coding bias of the researcher.

\section{A Brief Comparison to TIESR Data}

For environmental human rights the TIESR data includes only 95 constitutions, which is 30 fewer than the set used here. This can be seen by the presence of $N / A$ in the last three columns of Tables 5, 6, and 7. Age discrepancies between TIESR and this data, such as for Albania and Argentina, are either due to using a constitution from a different year (Albania) or considering the age based on the most recent amendment (Argentina). For an empirical analysis, the year in which the constitution was written is important to consider because it could be different from the year in which the environmental human rights provision was included. Nonetheless, there are few age discrepancies between the two sets of data.

In the TIESR data, there are 26 constitutions that include the right to access to food and/or water (FOWA), 11 of which are coded as directive principles while the other 15 are enforceable law. There are 63 constitutions that include the right to a healthy environment (HENV), split between directive principles (24) and enforceable law (39). Lastly, there are 73 constitutions that include the duty of the State to protect the environment (ENVP), 41 of which are coded as directive principles and 32 are coded as enforceable law.

Table 10 displays correlation coefficients between the categories discussed above and FOWA, HENV, and ENVP. ${ }^{24}$ For the full sample comparison of 95 countries, FOWA, HENV, and ENVP are, in general, positively correlated with most of the keyword categories with

\footnotetext{
${ }^{24}$ Comparing FOWA to this data may be misleading because it includes food, not just water.
} 
the exception of a few arguably independent correlations and a negative correlation between Category Two and FOWA and HENV, and Category Six and FOWA. The TIESR data are positively and statistically significantly correlated with the index totals from this data, indicating that the presence of more categories of language is positively related to coding the provisions as directive principles or enforceable law. Since the correlations are not equal to one, the remaining variation in the TIESR coding could likely be attributed to the subjective coding of the data. In other words, if these correlations were statistically no different from one, then the positive and subjective coding methods would arguably be perfect substitutes (empirically speaking). But this is not the case based on the coefficient values resulting from the simple linear or pairwise correlations. In fact, the positive association is dampened using pairwise correlations.

The last three rows of Table 10 display the pairwise correlation coefficients between this data and the data from TIESR. ${ }^{25}$ The pairwise correlations between FOWA, HENV, and ENVP are considerably strong, positive, and statistically significant. It seems that constitutions that have one, tend to have the other, which from a multicolinearity perspective, could seriously complicate any empirical analysis using this subset of TIESR data to explain environmental human rights outcomes. Furthermore, that there are a variety of both positive and negative, as well as statistically significant and otherwise, correlations with the language categories proposed in this analysis, could lead one to question the methodology behind coding these rights as directive principles versus enforceable law. Case law and specific legal ramifications would likely be a better indicator of the effect of specific constitutional environmental human rights provisions.

\footnotetext{
${ }^{25}$ The pairwise correlation coefficient uses a different method to handle missing observations, notably the pairwise deletion of observations compared to the listwise or casewise deletion of missing observations using the simple linear correlation.
} 


\section{Conclusion}

This analysis provides insight into the extent to which countries are taking environmental human rights seriously as evidenced through a keyword analysis of constitutional provisions. Out of 142 national constitutions that mention the environment, 125 contain a direct environmental human right or at least the basis of one, and ten include a direct human right to water. These provisions tend to be, on average, in younger constitutions of developing and Non-OECD countries. Yet, while many constitutions are sympathetic to environmental human rights, no two provisions are worded the same across countries. This is both a blessing and a curse. On the one hand, this allows for a direct positive interpretation of the provisions based solely on language while, on the other hand, it complicates any systematic attempt at a subjective interpretation of justiciability across countries. This is the primary difference in the data described here compared to that of TIESR, a difference that may or may not seriously complicate any empirical analysis using both sets of data. A second major difference is that TIESR explicitly delineates two general environmental human rights in HENV and ENVP while this paper does not take such a stand. Instead, the data in this analysis are treated like a single provision where the presence of more categories of language indicates a stronger (in a legal sense) constitutional environmental human rights provision.

Further research is necessary to determine if constitutions matter, specifically if constitutional environmental human rights provisions have any appreciable effect on environmental rights outcomes. Taking into consideration the strength of these provisions, which is typically static across time, is an important first step in this direction. However, time-varying

measures of government effort to respect, protect, and fulfill environmental human rights are arguably more robust indicators of the effects of constitutional provisions on outcomes. 
Table 1: Mention or Not, with Age of the Constitution, by Country Type (N=198)

\begin{tabular}{|c|c|c|c|c|c|}
\hline & Developed & Developing & OECD & Non-OECD & All Countries \\
\hline MENTION & 22 & 120 & 24 & 118 & 142 \\
\hline Average Age & 48.09 & 21.38 & 44.13 & 21.73 & 25.51 \\
\hline Median Age & 36.00 & 18.00 & 31.00 & 18.00 & 18.00 \\
\hline Std. Dev. & 42.71 & 19.87 & 42.08 & 20.22 & 26.44 \\
\hline NO MENTION & 12 & 44 & 8 & 48 & 56 \\
\hline Average Age & 92.00 & 36.73 & 114.13 & 37.65 & 49.43 \\
\hline Median Age & 77.50 & 32.00 & 117.50 & 33.00 & 37.00 \\
\hline Std. Dev. & 63.70 & 29.19 & 64.94 & 29.34 & 45.33 \\
\hline TOTAL & 34 & 164 & 32 & 166 & 198 \\
\hline Average Age & 63.59 & 25.49 & 61.63 & 26.33 & 32.04 \\
\hline Median Age & 50.00 & 19.00 & 44.00 & 19.00 & 19.50 \\
\hline Std. Dev. & 54.47 & 23.65 & 56.70 & 24.24 & 34.17 \\
\hline \% MENTION & $65 \%$ & $73 \%$ & $75 \%$ & $71 \%$ & $72 \%$ \\
\hline
\end{tabular}

Source: Author's calculations. 
Table 2: Mention or Not, with Age of the Constitution, by Continent (N=198)

\begin{tabular}{|c|c|c|c|c|c|c|c|}
\hline & Africa & Asia & Europe & Australia & North America & South America & All Countries \\
\hline MENTION & 38 & 37 & 35 & 7 & 13 & 12 & 142 \\
\hline Average Age & 16.21 & 24.11 & 31.31 & 41.00 & 27.62 & 31.08 & 25.51 \\
\hline Median Age & 17.00 & 18.00 & 18.00 & 31.00 & 27.00 & 20.50 & 18.00 \\
\hline Std. Dev. & 9.70 & 20.24 & 36.10 & 31.54 & 19.57 & 41.36 & 26.44 \\
\hline NO MENTION & 13 & 12 & 7 & 9 & 15 & $\mathrm{~N} / \mathrm{A}$ & 56 \\
\hline Average Age & 28.31 & 36.77 & 75.00 & 46.00 & 62.33 & $\mathrm{~N} / \mathrm{A}$ & 49.43 \\
\hline Median Age & 26.00 & 38.00 & 66.00 & 35.00 & 34.00 & $\mathrm{~N} / \mathrm{A}$ & 37.00 \\
\hline Std. Dev. & 14.14 & 24.78 & 59.91 & 34.27 & 63.70 & $\mathrm{~N} / \mathrm{A}$ & 45.33 \\
\hline TOTAL & 51 & 49 & 42 & 16 & 28 & 12 & 198 \\
\hline Average Age & 19.06 & 28.13 & 38.60 & 43.81 & 46.21 & 31.08 & 32.04 \\
\hline Median Age & 18.00 & 19.00 & 19.00 & 33.50 & 31.50 & 20.50 & 19.50 \\
\hline Std. Dev. & 12.09 & 22.03 & 43.33 & 32.11 & 50.84 & 41.36 & 34.17 \\
\hline \% MENTION & $75 \%$ & $76 \%$ & $83 \%$ & $44 \%$ & $46 \%$ & $100 \%$ & $72 \%$ \\
\hline
\end{tabular}

Source: Author's calculations. 
Table 3: Included and Excluded/Absent, with Age of the Constitution, by Country Type $(\mathrm{N}=198)$

\begin{tabular}{|c|c|c|c|c|c|}
\hline & Developed & Developing & OECD & Non-OECD & All Countries \\
\hline INCLUDED & 18 & 107 & 20 & 105 & 125 \\
\hline Average Age & 41.28 & 20.52 & 37.20 & 20.90 & 23.51 \\
\hline Median Age & 33.00 & 18.00 & 23.50 & 18.00 & 18.00 \\
\hline Std. Dev. & 43.42 & 20.21 & 41.86 & 20.62 & 25.71 \\
\hline EXCLUDED & 16 & 57 & 12 & 61 & 73 \\
\hline Average Age & 88.69 & 34.82 & 102.33 & 35.67 & 47.23 \\
\hline Median Age & 77.00 & 31.00 & 87.00 & 32.00 & 36.00 \\
\hline Std. Dev. & 55.88 & 26.82 & 56.03 & 27.17 & 41.81 \\
\hline TOTAL & 34 & 164 & 32 & 166 & 198 \\
\hline Average Age & 63.59 & 25.49 & 61.63 & 26.33 & 32.04 \\
\hline Median Age & 50.00 & 19.00 & 44.00 & 19.00 & 19.50 \\
\hline Std. Dev. & 54.47 & 23.65 & 56.70 & 24.24 & 34.17 \\
\hline \% MENTION & $53 \%$ & $65 \%$ & $63 \%$ & $63 \%$ & $63 \%$ \\
\hline
\end{tabular}


Table 4: Included and Excluded/Absent, with Age of the Constitution, by Continent $(\mathrm{N}=198)$

\begin{tabular}{|c|c|c|c|c|c|c|c|}
\hline & Africa & Asia & Europe & Australia & North America & South America & All Countries \\
\hline INCLUDED & 34 & 33 & 33 & 4 & 9 & 12 & 125 \\
\hline Average Age & 15.47 & 22.52 & 29.18 & 35.25 & 21.44 & 31.08 & 23.51 \\
\hline Median Age & 15.50 & 18.00 & 18.00 & 33.00 & 23.00 & 20.50 & 18.00 \\
\hline Std. Dev. & 9.78 & 18.67 & 35.91 & 6.85 & 19.03 & 41.36 & 25.71 \\
\hline EXCLUDED & 17 & 16 & 9 & 12 & 19 & $\mathrm{~N} / \mathrm{A}$ & 73 \\
\hline Average Age & 26.94 & 36.88 & 65.80 & 46.67 & 57.95 & $\mathrm{~N} / \mathrm{A}$ & 47.23 \\
\hline Median Age & 24.00 & 38.00 & 59.00 & 33.50 & 34.00 & $\mathrm{~N} / \mathrm{A}$ & 36.00 \\
\hline Std. Dev. & 12.87 & 25.23 & 54.65 & 36.84 & 57.14 & $\mathrm{~N} / \mathrm{A}$ & 41.81 \\
\hline TOTAL & 51 & 49 & 42 & 16 & 28 & 12 & 198 \\
\hline Average Age & 19.06 & 28.13 & 38.60 & 43.81 & 46.21 & 31.08 & 32.04 \\
\hline Median Age & 18.00 & 19.00 & 19.00 & 33.50 & 31.50 & 20.50 & 19.50 \\
\hline Std. Dev. & 12.09 & 22.03 & 43.33 & 32.11 & 50.84 & 41.36 & 34.17 \\
\hline \% INCLUDED & $67 \%$ & $67 \%$ & $79 \%$ & $25 \%$ & $32 \%$ & $100 \%$ & $63 \%$ \\
\hline
\end{tabular}

Source: Author's calculations. 


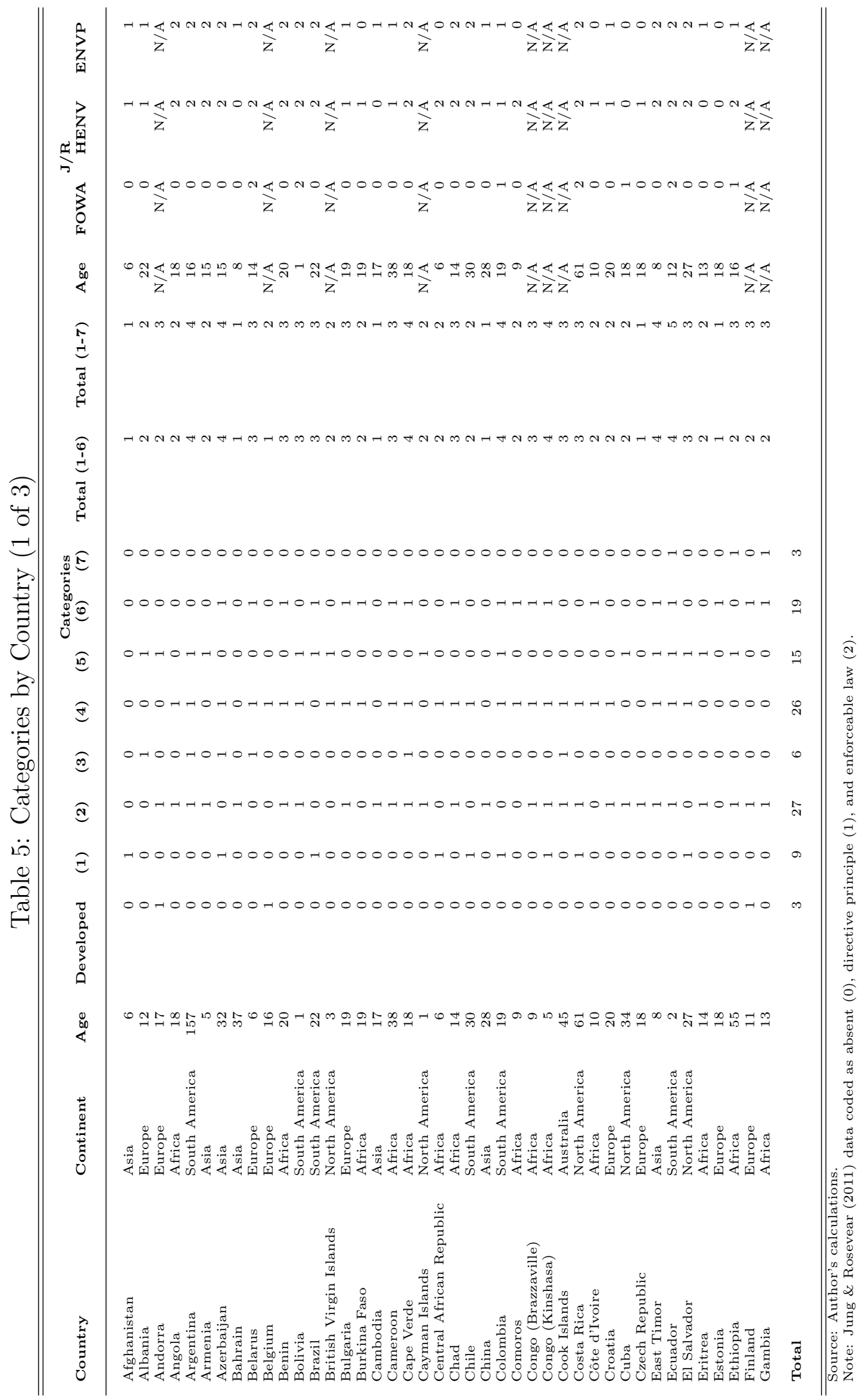




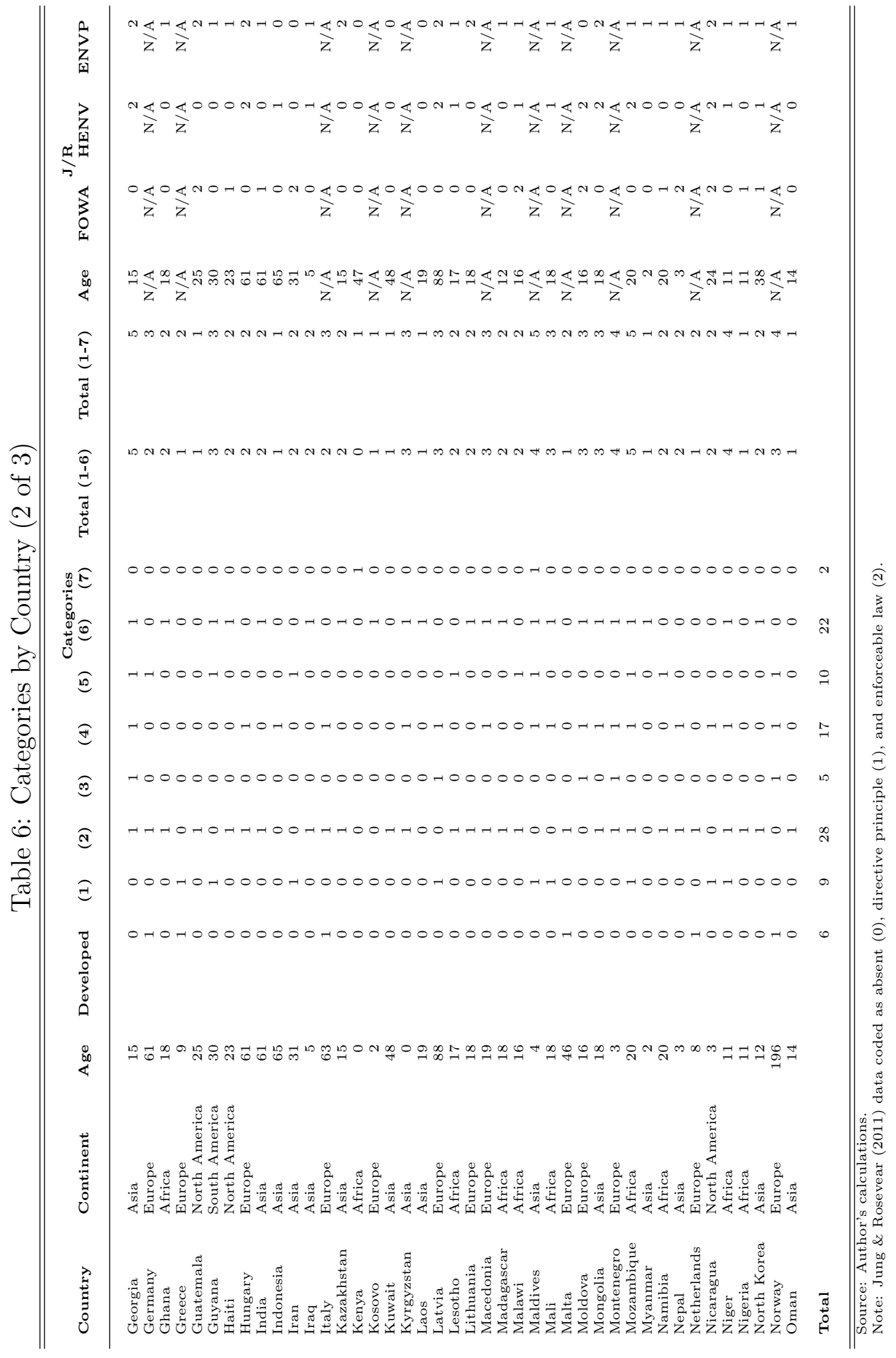




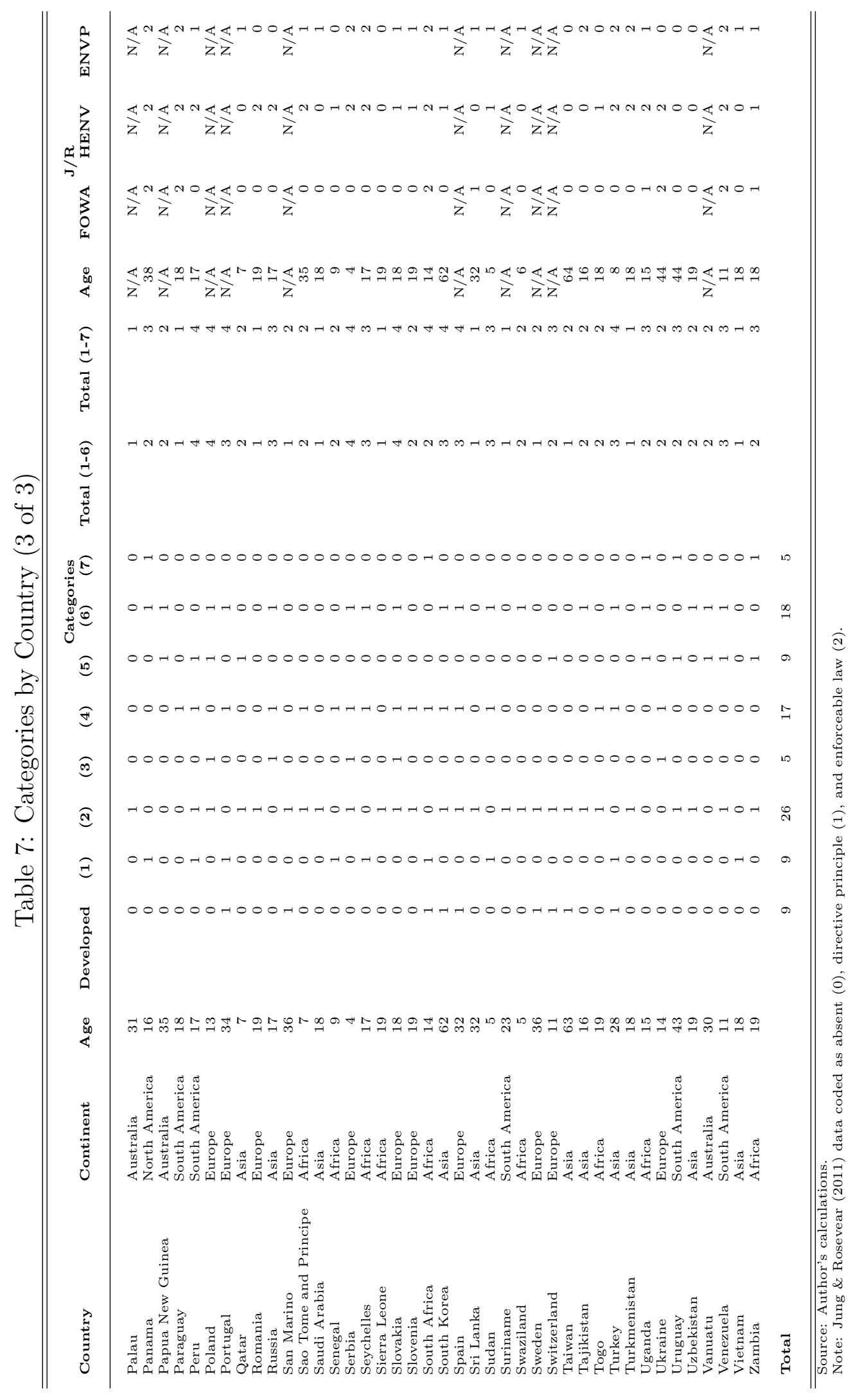


Table 8: Language Category Count by Age and Development Status ( $\mathrm{N}=125)$

\begin{tabular}{|c|c|c|c|c|c|}
\hline \multirow[b]{2}{*}{ Category Sum } & \multirow[b]{2}{*}{ Count } & \multirow[b]{2}{*}{$\%$ of Total Count } & \multirow[b]{2}{*}{ Average Age } & \multicolumn{2}{|c|}{ Count } \\
\hline & & & & Developed & Developing \\
\hline \multicolumn{6}{|c|}{ For Categories 1-6 } \\
\hline 0 & 1 & $0.80 \%$ & $\mathrm{~N} / \mathrm{A}$ & 0 & 1 \\
\hline 1 & 30 & $24.00 \%$ & 24.00 & 7 & 23 \\
\hline 2 & 51 & $40.80 \%$ & 20.00 & 6 & 45 \\
\hline 3 & 27 & $21.60 \%$ & 31.59 & 5 & 22 \\
\hline 4 & 14 & $11.20 \%$ & 22.21 & 0 & 14 \\
\hline 5 & 2 & $1.60 \%$ & 17.50 & 0 & 2 \\
\hline 6 & 0 & $0.00 \%$ & $\mathrm{~N} / \mathrm{A}$ & 0 & 0 \\
\hline Total/Average & 125 & $100 \%$ & 23.51 & 18 & 107 \\
\hline \multicolumn{6}{|c|}{ For Categories 1-7 } \\
\hline 0 & 0 & $0.00 \%$ & $\mathrm{~N} / \mathrm{A}$ & 0 & 0 \\
\hline 1 & 31 & $24.80 \%$ & 23.23 & 7 & 24 \\
\hline 2 & 44 & $35.20 \%$ & 19.20 & 5 & 39 \\
\hline 3 & 34 & $27.20 \%$ & 30.24 & 6 & 28 \\
\hline 4 & 12 & $9.60 \%$ & 25.42 & 0 & 12 \\
\hline 5 & 4 & $3.20 \%$ & 10.25 & 0 & 4 \\
\hline 6 & 0 & $0.00 \%$ & $\mathrm{~N} / \mathrm{A}$ & 0 & 0 \\
\hline 7 & 0 & $0.00 \%$ & $\mathrm{~N} / \mathrm{A}$ & 0 & 0 \\
\hline Total/Average & 125 & $100 \%$ & 23.51 & 18 & 107 \\
\hline
\end{tabular}

Source: Author's calculations. 


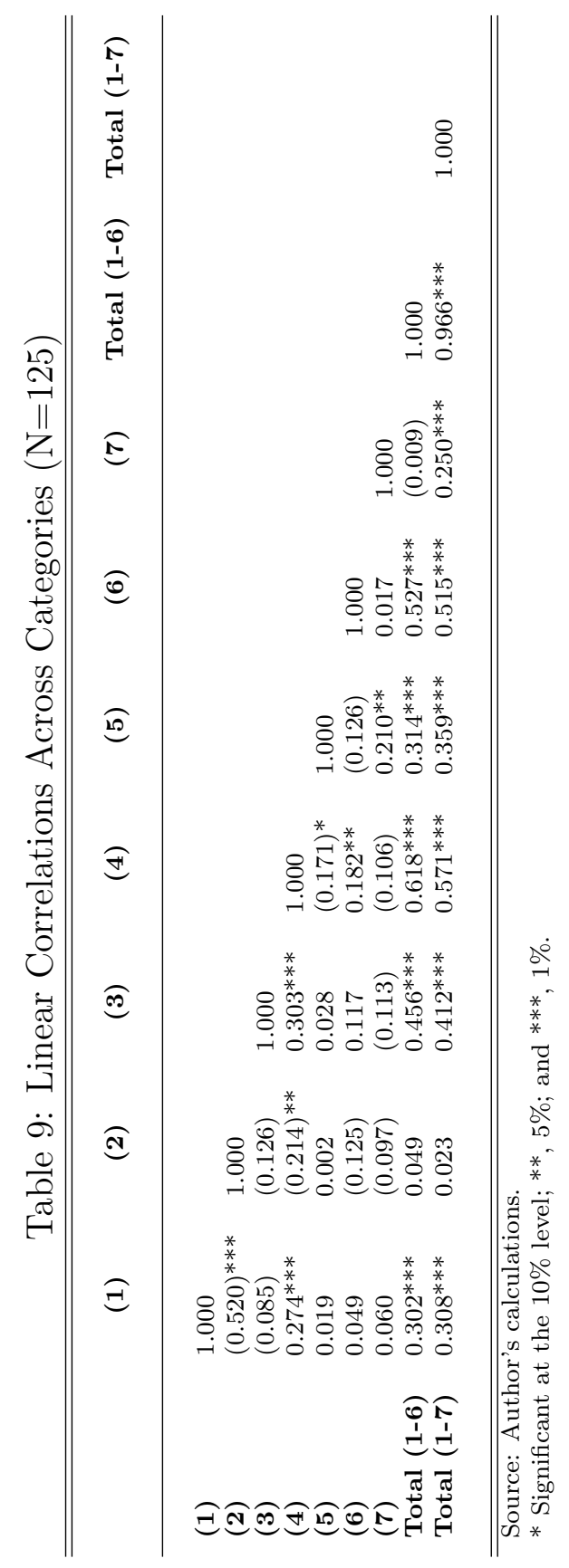




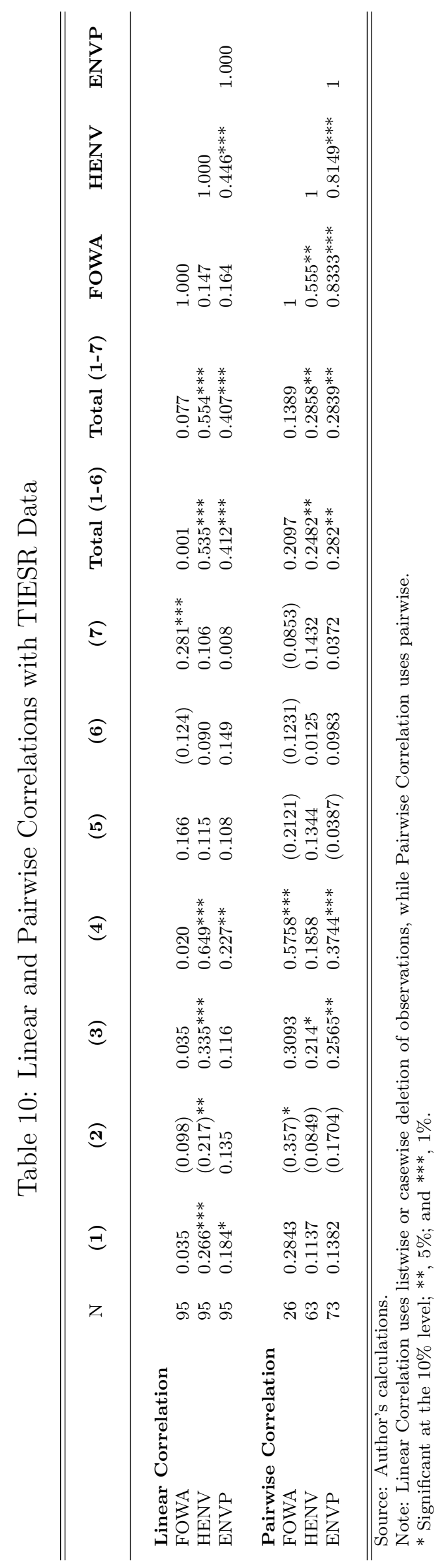


Figure 1: Language Count by Category

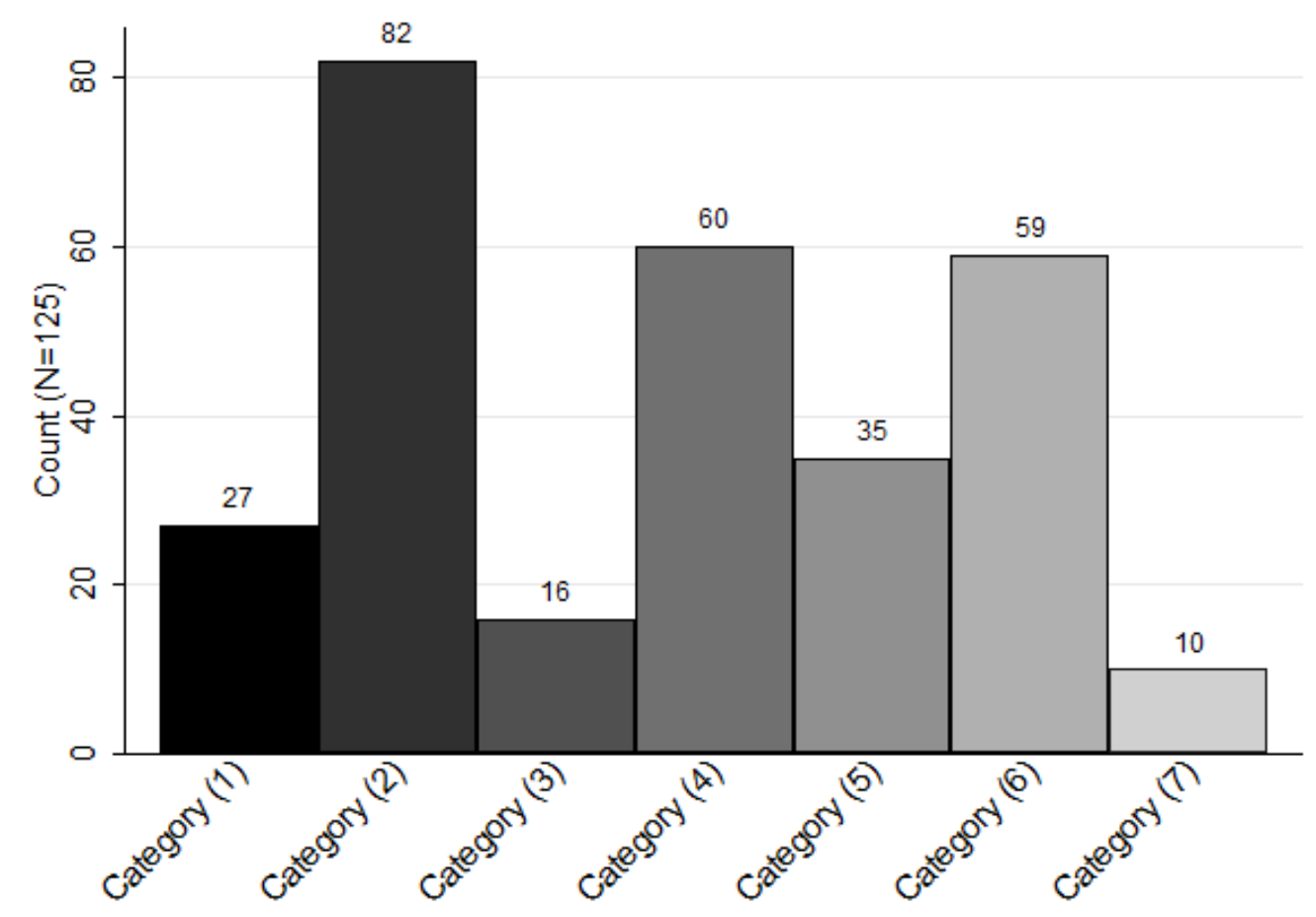


Figure 2: Summation Across Categories 1-6, All Countries (N=125)

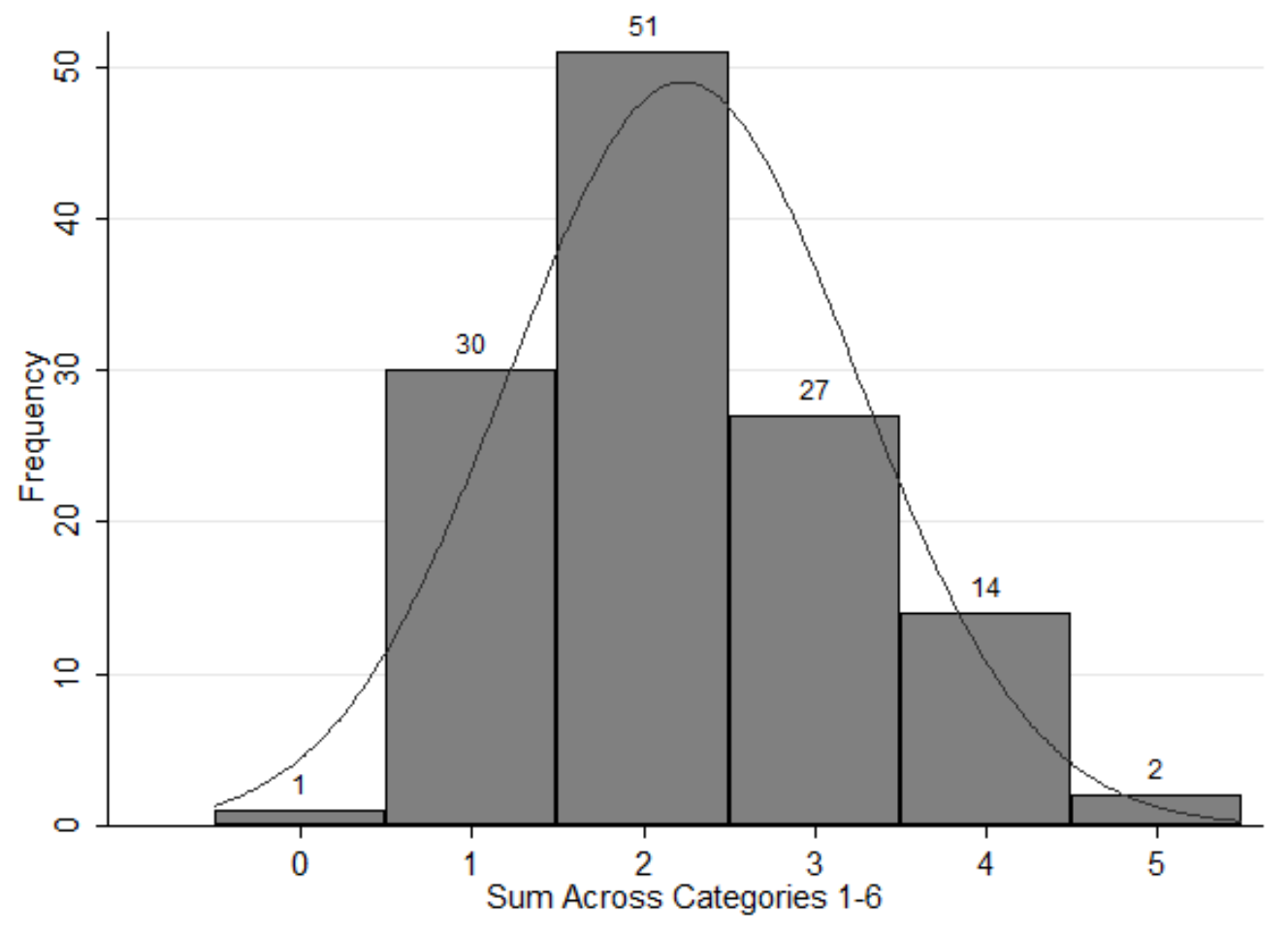


Figure 3: Summation Across Categories 1-7, All Countries (N=125)

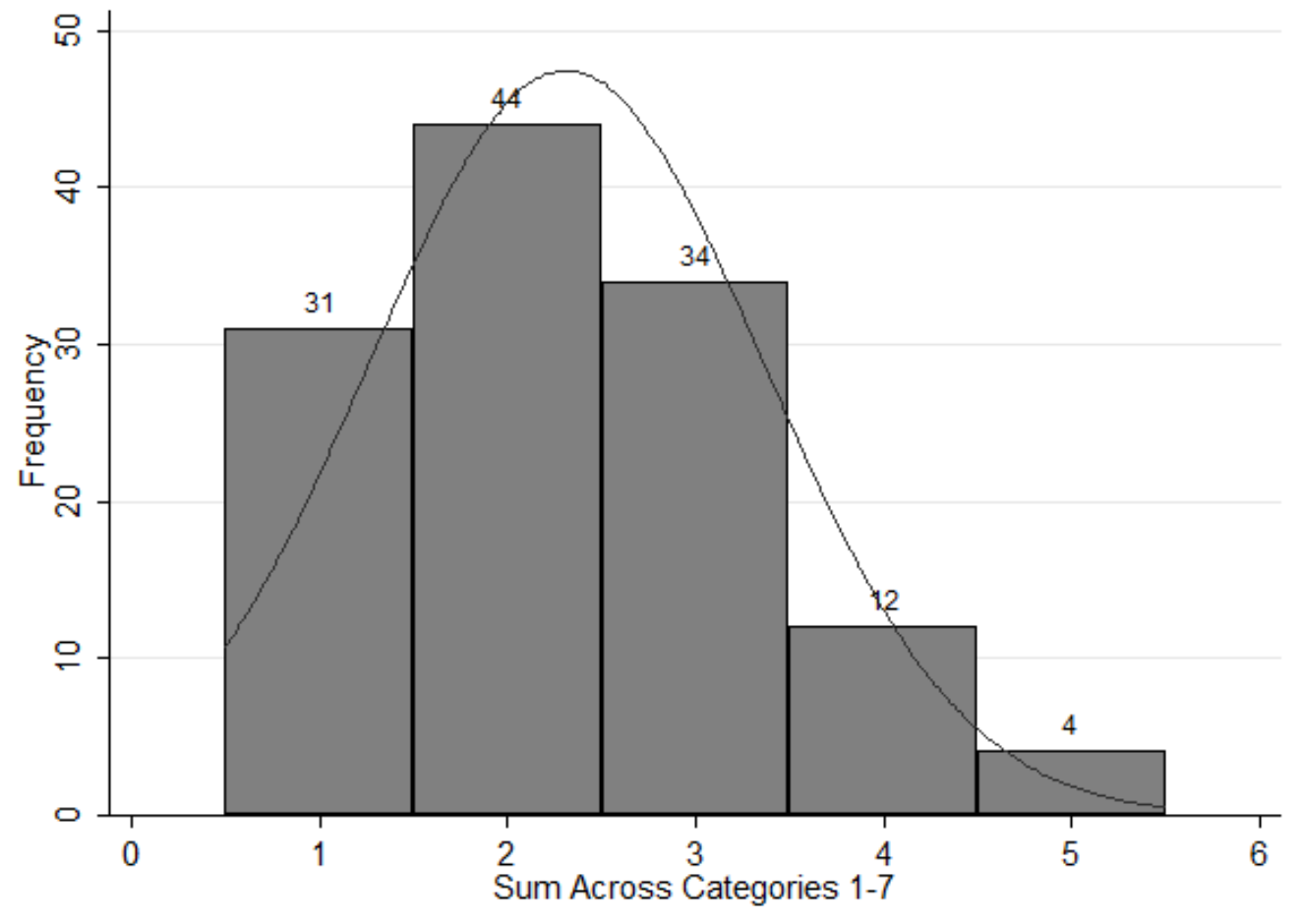




\section{References}

Barrett, C. (1996). Fairness, Stewardship and Sustainable Development. Ecological Economics, 19(1), 11-17.

Beckerman, W. (1997). Debate: Intergenerational Equity and The Environment. Journal of Political Philosophy, 5(4), 392-405.

Collins-Chobanian, S. (2000). Beyond Sax and Welfare Interests. Environmental Ethics, 22, 133-148.

Gleick, P. (1998). The Human Right to Water. Water Policy, 1-5, 487-503.

Hardin, G. (1968). The Tragedy of The Commons. Science (New York, NY), 162.

Herz, R. (2000). Litigating Environmental Abuses Under the Alien Tort Claims Act: A Practical Assessment. Virginia Journal of International Law, 40, 545-632.

Hiskes, R. (2009). The Human Right to a Green Future. Cambridge University Press.

Hiskes, R. (2010). Environmental Human Rights. Routledge International Handbooks. Cushman, T. (ed.s).

Howarth, R. (1997). Sustainability as Opportunity. Land Economics, 73(4), 569-579.

Jeffords, C., \& Shah, F. (2011). On the Natural and Economic Difficulties to Fulfilling the Human Right to Water. University of Connecticut Human Rights Institute Economic Rights Working Paper Series (Forthcoming).

Jung, C., \& Rosevear, E. (2011). Economic and Social Rights in Developing Country Constitutions: Preliminary Report on the TIESR Dataset. Draft for comment, University of Toronto. 
Lercher, A. (2007). Are There Any Environmental Rights?. Environmental Values, 16(3), $355-368$.

Minkler, A. (2009). Economic Rights and Political Decision Making. Human Rights Quarterly, $31(2), 368-393$.

Ostrom, E. (1990). Governing the Commons: The Evolution of Institutions for Collective Action. Cambridge University Press.

Padilla, E. (2002). Intergenerational Equity and Sustainability. Ecological Economics, 41(1), 69-83.

Rawls, J. (1999). A Theory of Justice. Belknap Press.

Sax, J. (1990). The Search for Environmental Rights. Journal of Land Use and Environmental Law, 6, 93-105.

Scanlon, J., Cassar, A., \& Nemes, N. (1999). Water as a Human Right?. UNESCO Courier.

Shelton, D. (1991). Human Rights, Environmental Rights, and the Right to Environment. Stanford Journal of International Law, 28, 103-138.

Shrader-Frechette, K. (2007). Human Rights and Duties to Alleviate Environmental Injustice: The Domestic Case. Journal of Human Rights, 6(1), 107-130.

Shue, H. (1996). Basic Rights: Subsistence, Affluence, and US Foreign Policy. Princeton University Press.

Sunstein, C. (2004). The Second Bill of Rights: FDR's Unfinished Revolution and Why We Need it More Than Ever. Basic Books.

United Nations: (2002). Economic and Social Council Committee on Economic, Social, and Cultural Rights General Comment No. 15. 
United Nations: (7/26/2010). General Assembly Document A/64/L.63/Rev.1.

Weiss, E. (1992). In Fairness to Future Generations and Sustainable Development. American University Journal of International Law and Policy, 8, 19. 